\title{
Faktor Penentu Kinerja Manajerial Sektor Kesehatan
}

\author{
Zaitul $^{1}$, Bayu Anugerah Putera ${ }^{2}$, dan Arie Frinola Minovia ${ }^{2}$ \\ ${ }^{1}$ Mahasiswa Jurusan Akuntansi, Fakultas Ekonomi, Universitas Bung Hatta, Padang, Indonesia \\ ${ }^{2}$ Dosen Fakultas Ekonomi dan Bisnis, Universitas Bung Hatta, Padang, Indonesia \\ Penulis korespondensi: zaitul@bunghatta.ac.id
}

\begin{abstract}
Abstrak
Penelitian ini bertujuan untuk menganalisis faktor-faktor penentu yang dapat meningkatkan kinerja manajerial pada sector kesehatan. Faktor-faktor tersebut terdiri dari partisipasi anggaran, informasi akuntansi, dan komitmen organisasi. kemudian gaya kepemimpinan sebagai variabel moderasi juga menjadi pendukung dalam menghubungkan faktor-faktor penentu pada kinerja manajerial. Pengambilan populasi dan sampel berdasarkan pada kepala bidang keuangan rumah sakit dan klinik yang ada di Kota Padang. Metode pemilihan sampel yang digunakan adalah simple random sampling. Teknik analisis yang digunakan dalam penelitian ini adalah Partial least square. Hasil pengungkapan dalam penelitian ini yaitu, partisipasi anggaran dan komitmen organisasi tidak berpengaruh terhadap kinerja manajerial, sedangkan informasi akuntansi memiliki pengaruh terhadap kinerja manajerial. Gaya kepemimpinan sebagai variabel moderasi dapat mempengaruhi kinerja manajerial, namun gaya kepemimpinan tidak dapat memoderasi hubungan antara partisipasi anggaran, informasi akuntansi dan komitmen organisasi dengan kinerja manajerial.
\end{abstract}

Kata Kunci: Partisipasi Anggaran, Informasi Akuntansi, Komitmen Organisasi, Kinerja Manajerial, Gaya Kepemimpinan

\begin{abstract}
The purpose of this study to analyze the determinant that can improve managerial performance. These factors are budget participation, accounting information, and organizational commitment. This study also investigate the role of leadership style as moderating variable between these factors and mangerial performance. the object of this study is financial manager in hospitals and clinics located in Padang, West Sumatera. Simple ramdom sampling is applied to sample population. Analytical technique in this study is used partial least square. The results of this study indicate that budget participation and organizational commitment have no effect on managerial performance. Meanswhile accounting information has an influence on managerial performance. The leadership style significantly influences managerial performance. However, the leadership style does not moderate the relationship between budget participation, accounting information and organizational commitment with managerial performance.
\end{abstract}

\section{Keyword: Budget Participation, Accounting Information, Organizational Commitment, Managerial Performance, Leadership Style}

\section{Pendahuluan}

Di awal tahun 2016, Indonesia telah memasuki era ekonomi baru dikawasan Asia Tenggara yaitu diberlakukannya Masyarakat Ekonomi ASEAN (MEA). Masyarakat Ekonomi ASEAN (MEA) merupakan salah satu bentuk integrasi ekonomi ASEAN yang akan membuka peluang dan tantangan bagi masyarakat Indonesia. Indonesia dan beberapa Negara ASEAN telah menyepakati perjanjian sebagai bentuk kerjasama melalui Masyarakat Ekonomi ASEAN (MEA). Umumnya yang berpartisipasi dalam MEA adalah organisasi yang memiliki sistem kinerja manajerial yang baik dan sistem penyusunan anggaran yang sudah tersusun rapi dan mampu di pahami. Salah satu organisasi yang berpartisipasi dalam MEA adalah organisasi dari sektor publik dalam bidang pelayanan jasa kesehatan. Salah satu organisasi yang bergerak dibidang pelayanan jasa kesehatan yaitu, rumah sakit dan klinik. Rumah sakit dan klinik yang ingin berpartispasi dalam MEA harus menerapkan prinsip manajaemen dengan benar.

Dari survey data tahun 2017 yang telah di lakukan pada salah satu Rumah Sakit yang ada di Kota Padang, yaitu RSUP Dr.M. Djamil Padang, dalam meningkatkan kinerja manajerialnya mampu memanfaatkan alokasi dana realisasi belanja operasional dan belanja modal (APBN-RM) dan relaisasi anggaran belanja operasional dan belanja modal BLU yang telah ditetapkan oleh DIPA RSUP Dr.M. Djamil Padang tahun 2017 sebesar Rp. 175.117.966.096,- atau sebesar 94,13\% dari alokasi DIPA Rutin sebesar Rp. 186.038.226.000, - dan Rp. 
373.435. 433. 603,- atau sebesar 96,91\% dari alokasi dana BLU sebesar Rp. 385. 362. 126. 000,-. (sumber: www.rsdjamil.co.id/)

Sehingga dari total perealisasian anggaran tersebut, RSUP Dr. M. Djamil Padang mampu mendukung hampir seluruh kinerja pelaksanaan program-program yang telah ada dalam mencapai target-target yang direncanakan. Namun, masih ada kinerja pelaksanaan program-program yang belum atau mendekati target yang telah direncanakan, seperti kurang baiknya mutu pelayanan, berkurangnya kunjungan dan lama hari perawatan pasien, perlunya penilaian transformasi budaya oleh lembaga independen yang ahli tentang budaya, fungsi pengawasan dan pengendalian belum optimal. Walaupun begitu, pencapaian kinerja pada tahun 2017 meningkat dibandingkan tahun 2016.

Penelitian tentang kinerja manajerial pada sektor kesehatan masih terabaikan oleh peneliti sebelumnya. Kebanyakan penelitian sebelumnya fokus pada kinerja manajerial pada perusahaan dan sekor publik, namun tidak sektor kesehatan [1]-[3]. Untuk peneliti ini mencoba mengisi celah literatur dengan meneliti faktor penentu kinerja manajerial di sektor kesrehatan. Keunikan lain dari penelitian ini adalah menguji faktor gaya kepemimpinan sebagai pemoderasi antra faktor penentu dan kinerja manajerial. Tujuan penelitian adalah untuk menganalisis dampak faktor penentu (partisipasi anggaran, informasi akuntansi, dan komitmen organisasi) terhadap kinerja manajerial. Penelitian ini juga menguji peran gaya kepemimpinan sebagai pemoderasi antara faktor penentu dan kinerja managerial. Makalah di bagai atas beberapa bagian, diantaranya adalah pendahuluan, teori dan pengembangan hipotesis, metode penelitian, hasil dan pembahasan, dan kesimpulan dan saran.

\section{Landasan Teori dan Pembahasan Hipotesis}

\section{Kinerja Manajerial}

Kinerja manajerial menurut [4], mengklasifikasikan peran manajer dalam tiga bidang utama yang bersifat teknis, konseptual dan manusia. Pengelolaan yang tepat dari fungsi inti yang disediakan khususnya konseptual dan manusia, dapat membuka jalan bagi peningkatan hasil dan pertumbuhan perusahaan. Menurut [5], Kinerja manajerial memberikan kemampuan kepada seorangmanajer dalam perencanaan, investigasi, koordinasi, penilaian, pengawasan, pekerjaan, negosiasi dan representasi. Kinerja manajerial tidak bisa disamakan dan bisa dibedakan dengan kinerja ekonomi unit yang menjadi tanggung jawab manajer. Salah satu faktor penting dalam perusahaan adalah kinerja manajerial. Oleh karena itu dengan meningkatnya kinerja manajerial, maka diharapkan adanya peningkatan pada kinerja perusahaan.
Terdapat beberapa teori yang menjelaskan hubungan dari variabel independen terhadap variabel dependen, yaitu (i) Goal Setting Theory, dan (ii) Contingency Theory. Goal Setting Theory dinyatakan oleh [6] menjelaskan jika seorang karyawan yang memiliki komitmen dan tujuan yang tinggi, maka akan mampu meningkatkan kinerja manajerial. Ketika tujuan prestasi mudah untuk dicapai maka akan menyebabkan sedikit usaha yang dikeluarkan. Apabila kesulitan tujuan bertambah sulit maka karyawan akan bekerja lebih keras, sehingga akan meningkatkan usaha. Teori penetapan tujuan menjelaskan bahwa ketika tingkat kesukaran tinggi, maka akan mengperlihatkan kinerja yang tinggi pula. Namun ketika tingkat kesukaran rendah, maka dapat memperlihatkan kinerja yang rendah pada Individu yang mempunyai kinerja tinggi. Meski demikian tingkat kesulitan tujuan tinggi dapat mengakibatkan frustasi terhadap individu yang mempunyai kinerja rendah.

Contingency Theory menjelaskan tidak terdapat suatu sistem pengendalian manajemen yang bisa diterapkan secara efektif dalam segala keadaan di sebuah organisasi, akan tetapi sistem pengendalian tertentu efektif apabila dalam kondisi organisasi tertentu. Kecocokan sistem pengendalian manajemen dengan variabel konseptual sebuah organisasi di hipotesiskan guna menghasilkan peningkatan kinerja serta individu yang ikut dalam organisasi tersebut [7]. [9] menyatakan bahwa ketika pendekatan kontinjensi digunakan, hal ini dimungkinkan terdapat variabel yang bertindak sebagai variabel mediasi atau variabel moderasi yang dapat mempengaruhi hubungan antara partisipasi anggaran dengan kinerja manajerial. Seperti penjelasan sebelumnya bahwa dalam teori kontinjensi variabel mediasi dan moderasi dapat berperan sebagai variabel yang memberikan pengaruh pada partisipasi anggaran terhadap kinerja manajerial. Dalam penelitian ini variabel moderasi yang digunakan yaitu gaya kepemimpinan.

\section{Partisipasi Anggaran}

Anggaran mempunyai dua fungsi utama di dalam sebuah perusahaan, yaitu sebagai alat perencanaan dan alat pengendalian manajemen. Kurangnya sebuang konsistensi dalam suatu anggaran, membuat konsistensi tersebut tidak menarik bagi penganggaran itu sendiri, tetapi konsistensi ini juga dapat digunakan dengan pengambila keputusan partisipatif, dan dasarankan sebuah kerangka kontingensi. Kerangka ini merupakan kerangka kerja yang dapat menunjukkan hubungan antara partisipasi anggaram dam kinerja atau kepuasan juga bergantung pada faktor-faktor lain [10].

[11] mendefinisikan partisipasi sebagai suatu proses mengevaluasi kinerja para individu dan menetapkan penghargaan atas dasar sasaran anggaran yang telah dicapai serta keterlibatan dan pengaruh 
para individu dalam penyusunan anggaran. Partisipasi anggaran sebagaimana didefinisikan dalam [12] adalah proses dimana seorang manajersepenuhnya bagian dari, mempengaruhi dan mengendalikan anggarannya. [13] menjelaskan dalam penelitiannya, bahwa hubungan partisipasi anggaran dengan kinerja manajerial menemukan hasil berpengaruh signifikan. Hasil penelitian dari [14] menjelaskan kinerja manajerial dapat dipengaruhi oleh partisipasi anggaran. Hal ini dapat mendorong manajer untuk berperan lebih aktif pada pelaksanaan anggaran dalam menghadapi kesulitan yang muncul.

\section{$H_{I}:$ Pengaruh partisipasi anggaran terhadap kinerja manajerial}

\section{Informasi Akuntansi}

Penilaian kinerja manajer dengan menggunakan informasi akuntansi melahirkan pro dan juga kontra yang mengundang peneliti untuk meneliti hal tersebut. Bidang Informasi akuntansi, sama halnya dengan sistem informasi akuntansi maupun sistem informasi yang mencakup beragam topik. Sifat praktik akuntansi terus berkembang pesat selama bertahun-tahun, terutama sistem informasi yang juga ikut berkembang. Pada abad kedua puluh, organisasi menghadapi masalah akuntansi baru yaitu manajemen pengetahuan [15]. Sehingga informasi akuntansi dapat digunakan menjadi suatu acuan dalam memperluas pengetahuan, baik secara tunggal atau dengan menggunakan informasi tambahan lainnya untuk menjadi dasar dalam mengukur prestasi bawah dalam pengetahuan manajemen.

Informasi akuntansi dapat mempengaruhi kinerja. Untuk dapat mencapai tujuan organisasi, manajer harus mampu membuat sebuah perencanaan yang akan diterapkan pada perusahaan. Pembuatan rencana tersebut membutuhkan pengambilan keputusan dengan tepat, agar sesuai dengan perencanan tersebut. oleh karena itu sebuah informasi dibutuhkan. Informasi yang dibutuhkan manajer biasanya adalah informasi akuntansi, karena didalamnya terdapat data-data yang dibutuhkan manajer untuk mengambil keputusan dalam pembuatan rencana di masa depan agar mampu meningkatkan kinerja dan mencapai tujuan perusahaan.

Bisa di jelaskan bahwa teknologi informasi yang dibutuhkan seorang manajer untuk kepentingan perusahaan, berasal dari informasi akuntansi. Dimana informasi akuntansi tersebut memiliki semua informasi, seperti anggaran yang ditetapkan untuk perancangan perencanaan pada masa yang akan datang. informasi akuntansi menjadi media penentu bagi seseorang dalam menjalankan kinerja. Dengan adanya informasi akuntansi, para manajer pun mampu menimbang setiap perencanaan yang dibuat agar rencana tersebut dapat dimaksimalkan dengan baik. Informasi akuntansi yang tercangkup di dalamnya anggaran, memberikan setiap data yang dibutuhkan manajer dalam membuat pertimbangan keputusan agar mampu menaikkan kualitas dari kinerja manajerial sebuah organisasi. Rencana yang disusun oleh manajer tersebut adalah kinerja.

Hasil penelitian dari [16] menjelaskan, kinerja manajerial dapat dipengaruhi secara signifikan oleh informasi. Hasil tersebut menjelaskan Semakin baik sebuah informasi maka akan semakin baik dan meningkat pula kinerja manajerial. Tetapi jika informasi yang dimiliki perusahaan buruk maka kinerja manajerialnya juga akan ikut buruk. Informasi akuntansi merupakan faktor yang penting bagi kinerja manajerial, karena bagi sebuah manajemen dalam melakukan perencanaan, koordinasi, dan evaluasi membutuhkan sebuah informasi dari informasi akuntansi. Begitu juga dengan hasil peneltian [17], bahwa informasi akuntansi memiliki pengaruh terhadap kinerja manajerial. Hasil ini dibuktikaan dengan adanya informasi kinerja yang komprehensif dan sistem pengukuran kinerja yang dapat menghasilkan infromasi lebih spesifik dan relevan dalam proses pengambilan keputusan yang dapat meningkatkan kinerja manajerial.

\section{$\mathrm{H}_{2}$ : Pengaruh informasi akuntansi terhadap kinerja manajerial}

\section{Komitmen Organisasi}

[18] menjelaskan komitmen organisasi sebagai tahap dimana karyawan mampu mngenali kelompok tertentu dengan tujuan untuk dapat mempertahankan status sebagai anggota kelompok. Selain itu komitmen organisasi diartikan sebagai (i) kesediaan yang kuat untuk tetap menjadi anggota kelompok, (ii) selalu bekerja kera agar menjadi aspirasi kelompok, (iii) bersedia untuk menerima nilai dan tujuan organisasi. Dengan kata lain, komitmen organisasi meruapakan perilaku yang memperlihatkan loyalitas seorang karyawan kepada organisasi dan di tahap selanjutnya karyawan tersebut dapat mengekspresikan kepedulian terhadap organisasi, keberhasilan dan pengembangan lebih lanjut. Sehingga, dapat dikatakan kinerja memiliki hubungan yang kuat dengan komitmen organisasi. Komitmen organisasi didefinisikan sebagai keyakinan yang internalisasi di antara anggota staf yang merupakan bagian dari mental mereka. Komitmen organisasi berpusat pada bidang yang berkaitan dengan nilai-nilai pribadi, status karir dan peluang, partisipasi kerja dan pengembangan kejuruan [19]. Penelitian [14] memberikan hasil yaitu, kinerja manajerial dapat dipengaruhi secara signifikan oleh komitmen organisasi. penelitiannya menjelaskan, organisasi yang memiliki karyawan berkomitmen, akan memperlihatkan sikap yang baik terhadap organisasi. Loyalitas tinggi muncul dari 
seorang karyawan apabila komitmen yang ia berikan sangat tinggi, dan ia akan berusaha untuk membela organisasi dalam mencapai tujuan organisasi. Penelitian [20] memberikan hasil, kinerja manajerial dapat terpengaruh oleh komitmen organisasi. Kesetiaan dibutuhkan dalam sebuah organisasi oleh setiap karyawan, sehingga dapat meningkatkan kinerja kearah yang lebih baik lagi.

\section{H3 : Pengaruh komitmen organisasi terhadap kinerja manajerial}

\section{Gaya Kepemimpinan}

Suatu organisasi dalam memotivasi karyawannya tidak lepas dari gaya kepemimpinan yang diterapkan organisasi. Gaya kepemimpinan secara luas sedang di teliti apakah memiliki hubungan terhadap kinerja, yang dapat dikenal sebagai kepemimpinan transformasional dan transaksional [18] Gaya kepemimpinan yang digunakan dalam mempengaruhi karyawan memiliki sebuah pola tingkah laku, sehingga kinerja dapat dimaksimalkan [13]. Menurut [21], terdapat empat macam gaya perilaku kepemimpinan yaitu, direktif, supportif, partipatif dan berorientasi pada prestasi. [16] dalam penelitiannya mengungkapkan, Gaya kepemimpinan merupakan sikap seorang manajer dalam berinteraksi di lingkungan organisasinya. Interaksi ini meliputi interaksi antara manajer dengan atasan, bawahan, dan kolega dari organisasinya tersebut. Untuk mencapai tujuan organisasi gaya kepemimpinan seorang manajer dan sikap bawahannya merupakan faktor keberhasilan mengelola suatu organisasi. Sehingga, jika para pemimpin memiliki dorongan yang kuat terhadap tugas-tugas kreatif karyawan, maka akan mempengaruhi kinerja pekerja itu sendiri. Jika kinerja pekerja itu telah dipengaruhi, maka akan muncul rasa yang kuat oleh pekerja untuk meningkatkan kinerjanya dan berusaha meningkatkan pencapaian tujuan perusahaan.

Penelitian dari [22] menyatakan bahwa gaya kepemimpinan tidak memiliki pengaruh terhadap kinerja manajerial. Penelitian yang dilakukan oleh [23], menyatakan bahwa kinerja manajerial mampu dipengaruhi secara positif oleh gaya kepemimpinan. gaya kepemimpinan memiliki pengaruh penting untuk meningkatkan pencapaian tujuan organisasi. Manajer yang mampu menerapkan gaya kepemimpinan sesuai dengan keinginan karryawan dapat membuat karyawan lebih berusaha untuk meningkatkan keoptimalan kinerja mereka.

\section{$H_{4}$ : Pengaruh gaya kepemimpinan terhadap kinerja manajerial}

Dalam penelitian ini, gaya kepemimpinan menjadi faktor moderasi dan dapat mempengaruhi faktor-faktor yang ada. Dalam teori kontinjensi telah menjelaskan bahwa adanya variabel intervening atau variabel moderasi mempengaruhi antara partisipasi anggaran dan kinerja manajerial. dalam hal ini gaya kepemimpinan menjadi variabel moderasi yang dapat mempengaruhi antara dua variabel tersebut. Pada dasarnya suatu organisasi di dalam memotivasi karyawan tidak dapat lepas dari gaya kepemimpinan yang diterapkannya. Dalam lingkungan organisasi terdapat interaksi antara bawahan, atasan, dan kolega, yang merupakan perilaku Gaya kepemimpinan seorang manajer. Sehingga, faktor kepemimpinan serta sikap bawahan dalam melaksanakan tugas dalam mencapai tujuan organisasi mendapatkan hasil yang baik dikarenakan keberhasilan pengelolaan suatu organisasi. [16]. Gaya kepemimpinan merupakan perwakilan dari filsafat, keterampilan, serta sikap pemimpin dalam politik [24]. Penelitian [16] menyatakan bahwa, partisiapasi anggaran mempengaruhi kinerja manajerial dan dimoderasi oleh gaya kepemimpinan. Hal ini menjelaskan sifat consideration dimiliki oleh variabel gaya kepemimpinan yang berarti terdapat hubungan antara pimpinan dan bawahan yang saling percaya dan saling memngawasi. Sehingga, bawahan memiliki kesempatan lain yang diberikan manajer agar berperan aktif menyusun partisipasi anggaran, sehingga dapat membuat peningkatan pada kinerja manajerial. Anggaran dan kinerja akan semakin baik, jika gaya kepemimpinan dapat diterapkan dengan tepat dan efektif. Sesuai dengan penjelasan dan penelitian sebelumnya, dapat kita tarik hipotesis seperti di bawah ini:

\section{H5: Partisipasi Anggaran berpengaruh terhadap Kinerja Manajerial dengan Gaya Kepemimpinan sebagai Variabel Moderasi.}

Manajemen membutuhkan kinerja yang memiliki sistem evaluasi, sehingga dapat melakukan evaluasi pada berbagai tingkat pertanggungjawaban kinerja manajer untuk memeriksa prestasi kinerja perusahaan. Informasi akuntansi adalah salah satu bentuk data dan informasi yang digunakan sebagai dasar sistem evaluasi kinerja manajer. Informasi dapat memberikan infromasi kepada manajer untuk membuat sebuah perencanaan dan menjadi acuan dalam mengambil keputusan. Perencanaan ini berfungsi dalam meningkatkan kinerja manajerial. Hasil penelitian oleh [16] menyatakn bahwa infromasi akuntansi memiliki pengaruh pada kinerja manajerial dimoderasi gaya kepemimpinan. Suatu gaya kepemimpinan yang baik yakni sebuah ikatan antara manajer dan karyawan yang mempunyai rasa percaya dan juga saling memperhatikan. Hal ini dapat meningkatkan kinerja perusahaan, sehingga karyawan memiliki perasaan lebih dihargai dan dapat melakukan pekerjaan yang lebih. Informasi yang tepat dengan diperkuat oleh gaya kepemimpinan dapat meningkatkan kinerja manajerial. Dengan 
begitu dapat kita ketahui bahwa gaya kepemimpinan dapat memoderasi informasi akuntansi agar dapat mempengaruhi kinerja manajerial untuk lebih meningkat lagi. Dari penjelasan ini dapat kita tarik hipotesis yakni:

\section{H6: Informasi Akuntansi bepengaruh terhadap Kinerja Manajerial dengan Gaya Kepmimpinan sebagai Variabel Moderasi.}

Jika pengelolaan manajemen tidak maksimal maka peningkatan dalam kinerja organisasi tidak akan tercapai. sehingga tidak mampu menjalankan setiap upaya dalam meningkatkan kinerja organisasi. Lingkungan perusahaan atau organisasi dapat menjadi faktor dalam mempengaruhi suatu kinerja, maka untuk mengendalikan faktor yang mempengaruhi tersebut, dibutuhkan sebuah indikator kinerja karyawan yaitu komitmen organisasi. Agar dapat mendorong para manajer, karyawan harus memiliki komitmen organisasi yang kuat dan usaha keras dalam mewujudkan tujuan organisasi dan juga meningkatkan kinerja operasi. Komitmen organisasi yang kuat biasanya tidak lepas dari gaya kepemimpinan seorang pemimpin dalam memimpin sebuah organisasi. Pada dasarnya komitmen karyawan akan menjadi tiga jenis yaitu, afektif, kognitif, dan normative. Yang menentukan bagaiman karyawan berkomitmen adalah gaya kepemimpin, jika gaya kepemimpinan tepat, maka karyawan pun akan berkomitmen sesuai dengan kepercayaan yang mereka miliki, misalnya, seorang karyawan mampu berkomitmen melebihi ketentuan yang telah disepakati bersama pemimpin perusahaan, dan itu akan berdampak baik bagi perusahaan tersebut, begitu pun sebaliknya. maka gaya kepemimpinan menjadi pengaruh yang membuat para karyawan akan terdorong dalam meningkatkan kinerja mereka dan mampu berkomitmen secara kuat dalam mencapai tujuan organisasi. Hasil penelitian dari [13] menjelaskan komitmen organisasi tidak memiliki pengaruh pada kinerja manajerial menggunakan gaya kepemimpinan sebagai variabel moderasi. Namun tidak bisa dipungkiri gaya kepemimpinan memiliki fungsi yang dapat mempengaruhi komitmen organisasi, sesuai dengan cara yang tepat. Jika gaya kepmimpinan tepat, maka komitmen organisasi pun akan menunjukkan hasil yang positif terhadap kinerja manajerial. oleh karena itu peneliti ingin mencoba meneliti kembali dampak yang ditimbulkan oleh gaya kepemimpinan sabagai variabel moderasi terhadap hubungan komitmen organisasi pada kinerja manajerial. dapat ditarik hipotesis seperti berikut:

\section{H7: Komitmen Organisasi berpengaruh terhadap Kinerja Manajerial dengan Gaya Kepemimpinan sebagai Variabel Moderasi.}

\section{Metode Penelitian}

Populasi dalam penelitian ini adalah Rumah Sakit dan Klinik Pemerintah maupun non Pemerintah di kota Padang. kusioner diharapkan diisi oleh kepala bidang keuangan. Metode pengambilan sampelnya adalah random sampling. Metode pengumpulan data dilakukan dengancara menyebar kuesioner (angket). Terdapat beberapa indikator dalam penentuan kriteria yang digunakan dalam kuesioner seperti jenis kelamin, umur, tingkat pendidikan dan lama bekerja. Seperti yang dilihatkan dalam kuesioner yang di paparkan [25] dimana pada kuesionernya terdapat beberapa karakteristik dalam menentukan responden yang akan diteliti. Kuesioner yang digunakan dalam penelitian ini menggunakan pengukuran skala likert. Pengukuran yang digunakan dalam penelitian ini adalah skala likert. Indikator yang terdapat pada kinerja manajerial ada sebanyak 8 indikator [26]. Untuk partisipasi anggaran terdapat 6 item indikator dengan pengukuran [27]. Sedangkan komitmen organisasi mempunyai sebanyak 9 item indicator [28]. Sedangakan untuk informasi akuntansi hanya memiliki 5 indikator [29]. Dan gaya kepemimpinan memiliki 8 indikator [25]. Model penelitian yang diaplikasikan pada penelitian ini adalah pendekatan Structural Equation Modeling (SEM) yang digunakn untuk menyelesaikan regresi berganda ketika terjadi permasalahan spesifik data, seperti ukuran sampel penelitian kecil, adanya data yang hilang dan multikolinearitas yang didesain.

\section{Analisis Dan Pembahasan}

Bagian ini membahas hasil penelitian dan pembahasan. Hasil analisa dimulai dengan profil responden, penilaian model pengukuran. Deskripsi data, model struktural dan uji hipotesis. Jumlah rumah sakit dan klinik yang terdapat dikota Padang berjumlah 134 buah. Dari 134 buah rumah sakit dan klinik tersebut, peneliti menggunakan rumus Slovin untuk menentukan jumlah sampel $\left(n=\mathrm{N} /\left(1+\mathrm{N}^{*} \mathrm{e}^{2}\right)\right.$ dengan $e=5 \%$, sehingga jumlah sampel menjadi 100 . Metode pengambilan sampel menggunakan metode simple random dengan undian. Jumlah kuesioner yang didistribusikan sebanyak 100 dan kembali sebanyak 50 unit. Berikut data karakteristik responden yang digunakan dalam penelitian ini. 
TABEL 4.1

KARAKTERISTIK DEMOGRAFI RESPONDEN

\begin{tabular}{|c|c|c|}
\hline 1. Nama Tempat & Jumlah & Presentase \\
\hline Rumah Sakit & 24 & $48 \%$ \\
\hline Klinik & 26 & $52 \%$ \\
\hline Total & 50 & $100 \%$ \\
\hline \multicolumn{3}{|l|}{ 2. Umur } \\
\hline$<25$ Tahun & 35 & $70 \%$ \\
\hline $\begin{array}{l}26-35 \\
\text { Tahun }\end{array}$ & 12 & $24 \%$ \\
\hline $\begin{array}{l}36-45 \\
\text { Tahun }\end{array}$ & 3 & $6 \%$ \\
\hline$>45$ Tahun & 0 & 0 \\
\hline Total & 50 & $100 \%$ \\
\hline \multicolumn{3}{|l|}{ 3. Jenis Kelamin } \\
\hline Laki - Laki & 34 & $68 \%$ \\
\hline Perempuan & 16 & $32 \%$ \\
\hline Total & 50 & $100 \%$ \\
\hline \multicolumn{3}{|l|}{$\begin{array}{l}\text { 4. Tingkat } \\
\text { Pendidikan }\end{array}$} \\
\hline Lulusan D3 & 6 & $12 \%$ \\
\hline Lulusan S1 & 44 & $88 \%$ \\
\hline Total & 50 & $100 \%$ \\
\hline \multicolumn{3}{|l|}{ 5. Lama Bekerja } \\
\hline $\begin{array}{l}1 \text { Tahun } \\
\text { Kerja }\end{array}$ & 24 & $48 \%$ \\
\hline $\begin{array}{l}3 \text { Tahun } \\
\text { Kerja }\end{array}$ & 21 & $42 \%$ \\
\hline $\begin{array}{l}>5 \text { Tahun } \\
\text { Kerja }\end{array}$ & 5 & $10 \%$ \\
\hline Total & 50 & $100 \%$ \\
\hline
\end{tabular}

Berdasarkan data yang di olah, dengan penyebaran kepada rumah sakit sebanyak 24 buah dan klinik sebanyak 26 buah dapat diuraikan beberapa karakteristik responden seperti umur, jenis kelamin, lama bekerja dan pendidikan. Karakteristik responden berdasarkan umur memperlihatkan bahwa responden dengan umur $<25$ tahun yang berjumlah 35 orang, di ikuti yang berumur 26 Tahun sampai 35 Tahun berjumlah 12 orang dan yang berumur 36 tahun hingga 45 tahun berjumlah 3 orang. Responden dengan umur $>45$ Tahun tidak ada sama sekali.

Demografi responden didomisili oleh laki-laki sejumlah 34 orang, sedangkan perempuan sejumlah 16 orang. Karakterstik responden berdasarkan tingkat pendidikan formal demografi responden didominasi oleh tingkat pendidikan S1 berjumlah 44 orang. Sedangkan tingkat pendidikan D3 hanya berjumlah 6 orang Karakteristik responden berdasarkan masa kerja memperlihatkan bahwa sudah bekerja selama 1 tahun sebanyak 24 orang, disusul yang telah bekerja 3 tahun, berjumlah 21 orang, dan sudah bekerja $>5$ tahun, berjumlah 5 orang.
TABEL 4.8

MEASUREMENT MODEL KINERJA MANAJERIAL COMPOSITEREABILITY DAN AVERAGEVARIENCE EXTRACTED

\begin{tabular}{|c|c|c|c|c|c|}
\hline Konstruk & item & $\begin{array}{c}\text { Outer } \\
\text { loadin } \\
g\end{array}$ & $\mathrm{CA}$ & $\mathrm{CR}$ & AVE \\
\hline \multirow{5}{*}{$\begin{array}{c}\text { Kinerja } \\
\text { manajerial }\end{array}$} & $\mathrm{Y} 1$ & 0,842 & \multirow{5}{*}{0,861} & \multirow{5}{*}{0,900} & \multirow{5}{*}{0,644} \\
\hline & $\mathrm{Y} 2$ & 0,811 & & & \\
\hline & Y3 & 0,719 & & & \\
\hline & Y4 & 0,802 & & & \\
\hline & Y5 & 0,833 & & & \\
\hline \multirow{5}{*}{$\begin{array}{l}\text { Partisipasi } \\
\text { Anggaran }\end{array}$} & X11 & 0,795 & \multirow{5}{*}{0,845} & \multirow{5}{*}{0,888} & \multirow{5}{*}{0,614} \\
\hline & $\mathrm{X} 12$ & 0,859 & & & \\
\hline & X13 & 0,744 & & & \\
\hline & X14 & 0,778 & & & \\
\hline & X16 & 0,734 & & & \\
\hline \multirow{5}{*}{$\begin{array}{l}\text { Informasi } \\
\text { Akuntansi }\end{array}$} & X21 & 0,899 & \multirow{5}{*}{0,898} & \multirow{5}{*}{0,925} & \multirow{5}{*}{0,714} \\
\hline & $\mathrm{X} 22$ & 0,846 & & & \\
\hline & X23 & 0,840 & & & \\
\hline & X24 & 0,916 & & & \\
\hline & $\mathrm{X} 25$ & 0,709 & & & \\
\hline \multirow{2}{*}{$\begin{array}{l}\text { Komitmen } \\
\text { Organisasi }\end{array}$} & X37 & 0,895 & \multirow{2}{*}{0,702} & \multirow{2}{*}{0,870} & \multirow{2}{*}{0,770} \\
\hline & X39 & 0,859 & & & \\
\hline \multirow{5}{*}{$\begin{array}{c}\text { Gaya } \\
\text { kepemimpina } \\
\mathrm{n}\end{array}$} & M1 & 0,852 & \multirow{5}{*}{0,870} & \multirow{5}{*}{0,906} & \multirow{5}{*}{0,660} \\
\hline & M2 & 0,752 & & & \\
\hline & M3 & 0,843 & & & \\
\hline & M4 & 0,868 & & & \\
\hline & M5 & 0,737 & & & \\
\hline
\end{tabular}

Sumber: Hasil olah data PLS, 2019

Hasil pengolahan data menggunakan smartPLS item-item yang terdapat pada variabel dependen kinerja manajerial ada beberapa yang di hapus karena mendapatkan hasil loading factor di bawah 0,7 yakni Y6, Y7, dan Y8. Hal ini serupa dengan penjelasan [30] menyatakan bahwa 0,70 atau diatasnya lebih disukai, tetapi jika ini merupakan penelitian eksplorasi maka nilai 0,4 atau diatasnya dapat diterima. Untuk hasil composite reability [31] menyatakan bahwa keandalan komposit 0,7 atau diatasnya. Jika penelitian ini merupakan penelitian eksplorasi, 0,6 atau diatasnya dapat diterima. Sehingga hasil yang diperoleh kurang dari 0,7 akan di hapus. Convergent validity tidak terlihat pada loading factor, namun hanya terlihat pada nilai average variance extracted (AVE). Menurut [31] AVE harus pada 0,5 atau lebih tinggi. Tidak terdapat convergent validity pada model yang di uji dalam penelitian ini, karena hasil AVE pada setiap konstruk di atas 0,5 .

Kemudian hasil pengolahan data menggunakan smartPLS item-item yang terdapat pada variabel independen partisipasi anggaran ada beberapa yang di hapus karena memiliki hasil loading factor dibawah 0,7 , yakni X15. Hal ini serupa dengan penjelasan [30] menyatakan bahwa 0,70 atau diatasnya lebih disukai, tetapi jika ini merupakan penelitian eksplorasi maka nilai 0,4 atau diatasnya dapat diterima. Untuk Hasil composite reability [31] 
menyatakan bahwa keandalan komposit 0,7 atau diatasnya. Jika penelitian ini merupakan penelitian eksplorasi, 0,6 atau diatasnya dapat diterima. Sehingga hasil yang diperoleh kurang dari 0,7 akan di hapus. Convergent validity tidak terlihat pada loading factor, namun hanya terlihat pada nilai average variance extracted (AVE). Menurut [31] AVE harus pada 0,5 atau lebih tinggi. Tidak terdapat convergent validity pada model yang di uji dalam penelitian ini, karena hasil AVE pada setiap konstruk di atas 0,5 .

Lalu hasil pengolahan data menggunakan smartPLS item-item yang terdapat pada variabel independen informasi akuntansi tidak ada iten yang di hapus karena memiliki nilai loading factor di atas 0,7. Hal ini serupa dengan penjelasan [30] menyatakan bahwa 0,70 atau diatasnya lebih disukai, tetapi jika ini merupakan penelitian eksplorasi maka nilai 0,4 atau diatasnya dapat diterima. Untuk hasil composite reability [31] menyatakan bahwa keandalan komposit 0,7 atau diatasnya. Jika penelitian ini merupakan penelitian eksplorasi, 0,6 atau diatasnya dapat diterima. Sehingga hasil yang diperoleh kurang dari 0,7 akan di hapus Convergent validity tidak terlihat pada loading factor, namun hanya terlihat pada nilai average variance extracted (AVE). Menurut [31] AVE harus pada 0,5 atau lebih tinggi Tidak terdapat convergent validity pada model yang di uji dalam penelitian ini, karena hasil AVE pada setiap konstruk di atas 0,5.

Hasil pengolahan data menggunakan smartPLS item-item yang terdapat pada variabel independen Komitmen organisasi ada beberapa yang di hapus karena terdapat hasil loading factor di bawah 0,7 yakni X31, X32, X33, X34, X35, X36, dan X38. Hal ini serupa dengan penjelasan [30] menyatakan bahwa 0,70 atau diatasnya lebih disukai, tetapi jika ini merupakan penelitian eksplorasi maka nilai 0,4 atau diatasnya dapat diterima. Untuk hasil composite reability [31] menyatakan bahwa keandalan komposit 0,7 atau diatasnya. Jika penelitian ini merupakan penelitian eksplorasi, 0,6 atau diatasnya dapat diterima. Sehingga nilai yang diperoleh kurang dari 0,7 akan di hapus. Convergent validity tidak terlihat pada loading factor, namun hanya terlihat pada nilai average variance extracted (AVE). Menurut [31] AVE harus pada 0,5 atau lebih tinggi Tidak terdapat convergent validity pada model yang di uji dalam penelitian ini, karena hasil AVE pada setiap konstruk di atas 0,5 .

Hasil pengolahan data menggunakan smartPLS item-item yang terdapat pada variabel independen Komitmen organisasi ada beberapa yang di hapus karena mempunyai hasil loading factor di bawah 0,7 yakni M7 dan M8. Namun stelah dilakukan eliminasi kembali terdapat satu item lagi yang harus dihapus karena nilai loading factornya memiliki nilai setara 0,7 namun berwarna merah yakni M6. Hal ini serupa dengan penjelasan [30] menyatakan bahwa 0,70 atau diatasnya lebih disukai, tetapi jika ini merupakan penelitian eksplorasi maka nilai 0,4 atau diatasnya dapat diterima. Untuk hasil composite reability [31] menyatakan bahwa keandalan komposit 0,7 atau diatasnya. Jika penelitian ini merupakan penelitian eksplorasi, 0,6 atau diatasnya dapat diterima. Sehingga hasil yang diperoleh kurang dari 0,7 akan di hapus Convergent validity tidak terlihat pada loading factor, namun hanya terlihat pada nilai average variance extracted (AVE). Menurut [31] AVE harus pada 0,5 atau lebih tinggi. Tidak terdapat convergent validity pada model yang di uji dalam penelitian ini, karena hasil AVE pada setiap konstruk di atas 0,5 .

\section{Penilaian Model Struktur}

Penilaian model struktur merupakan hubungan antara variabel dan item. Penelitian ini mempunyai tiga variabel independen, satu variabel dependen, dan satu variabel moderasi. Penelitian.model struktural di evaluasi dengan menggunakan analisis $R$-square. Intuk konstruk dependen uji t serta signifikasi dari koefisien parameter jalur structural. Hasil analisis akan muncul dari model structural pada PLS yang dievaluasi dengan memanfaatkan $R$-square seperti tabel di bawah ini:

TABEL 4.7

STRUKTURAL MODEL

\begin{tabular}{|c|c|c|}
\hline $\begin{array}{c}\text { Endogeneous } \\
\text { Construct }\end{array}$ & $R$-Square & $Q$-Square \\
\hline Kinerja Manajerial & 0,758 & 0,398 \\
\hline
\end{tabular}

Sumber: Hasil olah data PLS, 2019

Model structural terbagi dalam dua kriteria yaitu predictive power dan predictive relevance. Pada predictive power nilai yang dilihat yaitu pada $\mathrm{R}^{2}$ sedangkan pada predictive relevance dilihat dari nilai $\mathrm{Q}^{2}$. Pengujian terhadap inner model ini memiliki tujuan untuk mengetahui berapa besar nilai variabel dependen dapat memaparkan variabel independen dalam inner model penelitian. Pengujian ini dengan menggunakan nilai $R$-Square, yang dalam hasil penelitian ini $R$-Square yang diperoleh variabel dependen kinerja manajerial ialah 0,758>0,2, sehingga bisa diintreprestasikan predictor laten dalam penelitian ini mempunyai pengaruh besar pada level structural dan nilai $\mathrm{Q}^{2} 0,398>0$, maka ini menjelaskan model tidak memiliki predictive relevance. Untuk menilai model dengan menggunakan PLS harus terlebih dahulu mencari nilai $R$-square pada variabel laten dependen. 


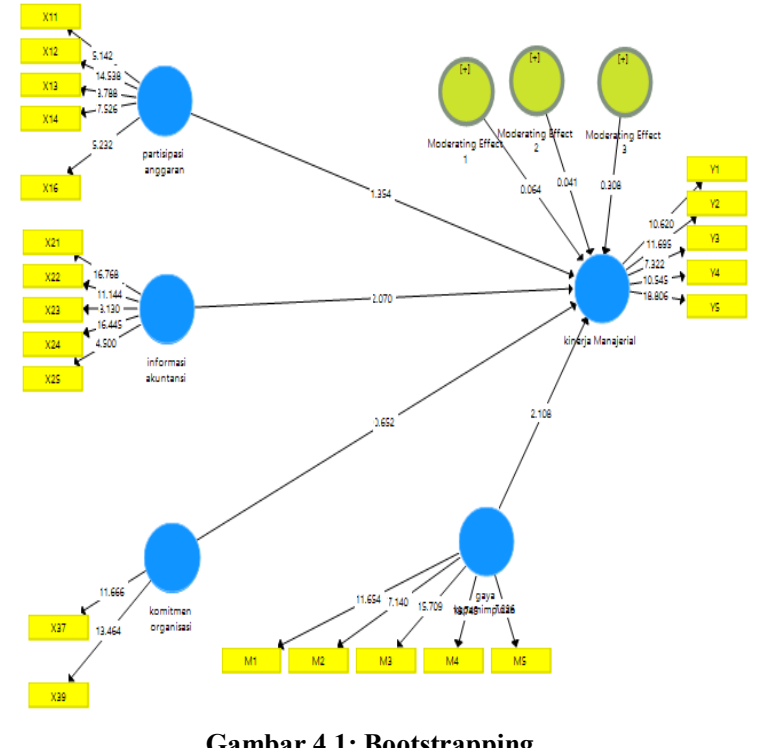

Gambar 4.1: Bootstrapping

\section{Hasil Uji Hipotesi}

\begin{tabular}{|c|c|c|l|}
\multicolumn{5}{c}{ T-STATISTIC } \\
\hline konstruk & t-statistic & P-Value & Keterangan \\
\hline PA -> KM & 1,354 & 0,176 & Ditolak \\
\hline IA -> KM & 2,070 & 0,039 & Diterima \\
\hline KO-> KM & 0,652 & 0,515 & Ditolak \\
\hline GK->KM & 2,108 & 0,036 & Diterima \\
\hline $\begin{array}{c}\text { Efek } \\
\text { Moderasi PA- } \\
\text { >KM }\end{array}$ & 0,064 & 0,949 & Ditolak \\
\hline $\begin{array}{c}\text { Efek } \\
\text { Moderasi IA- } \\
>\text { KM }\end{array}$ & 0,041 & 0,967 & Ditolak \\
\hline $\begin{array}{c}\text { Efek } \\
\text { Moderasi } \\
\text { KO->KM }\end{array}$ & 0,308 & 0,758 & Ditolak \\
\hline
\end{tabular}

Sumber: Hasil olah data PLS, 2019

Hipotesis pertama memperlihatkan adanya pengaruh terhadap kinerja manajerial oleh partisipasi anggaran. Dari hasil perhitungan smartPLS menjelaskan bahwa partisipasi anggaran tidak memiliki pengaruh terhadap kinerja manajerial. Untuk membuktikan nilai p-values harus melebihi nilai koefisien yaitu, 0,05 . Dalam penelitian ini nilai p-values partisipasi anggaran adalah 0,176 . Nilai pvalues tersebut besar dari nilai koefisien 0,05 . Sehingga hipotesis tidak berpengaruh, artinya hipotesis pertama ditolak. Hipotesis kedua memperlihatkan adanya pengaruh kinerja manajerial oleh Informasi Akuntansi. Hasil perhitungan smartPLS menjelaskan bahwa informasi akuntansi memiliki pengaruh terhadap kinerja manajerial. Untuk menentukan hasilnya tersebut, nilai p-values harus kecil dari nilai koefisien yaitu, 0,05. Dalam penelitian ini nilai p-values informasi akuntansi yaitu 0,039 yang berarti nilai $p$-values kecil dari nilai koefisien 0,05. Sehingga, hipotesis memiliki pengaruh, artinya hipotesis kedua diterima.
Hipotesis ketiga memperlihatkan kinerja manajerial tidak dipengaruhi oleh komitmen organisasi. Untuk membuktikan kinerja manajerial tidak dipengaruhi oleh komitmen organisasi, nilai pvalues harus lebih besar dari nilai koefisien yaitu, 0,05. Dari hasil perhitungan smartPLS menjelaskan bahwa nilai $\mathrm{p}$-values komitmen organisasi sebesar 0,515 , yang berarti nilai p-values besar dari nilai koefisien 0,05 . Sehingga hipotesis tidak memiliki pengaruh, artinya hipotesis ketiga ditolak. Hipotesis keempat memperlihatkan kinerja manajerial dipengaruhi oleh gaya kepemimpinan. Hasil perhitungan smartPLS menjelaskan gaya kepemimpinan memiliki pengaruh terhadap kinerja manajerial. Untuk menentukannya, nilai p-values harus kecil dari nilai koefisien yaitu, 0,05. Dalam penelitian ini nilai p-values informasi akuntansi sebesar 0,036 kecil dari nilai koefisien. Sehingga hipotesis memiliki pengaruh, artinya hipotesis keempat diterima.

Hipotesis kelima menyatakan kinerja manajerial yang dimoderasi gaya kepemimpinan dipengaruhi partisipasi anggaran. Untuk membuktikan hasil tersebut, nilai p-values harus melebihi nilai koefisien yaitu, 0,05. Dari hasil perhitungan smartPLS menjelaskan nilai p-values partisipasi anggaran terhadap kinerja manajerial dengan efek moderating sebesar 0,949, lebih besar dari nilai koefisien 0,05. Sehingga dapat disimpulkan, hipotesis tidak berpengaruh, artinya hipotesis kelima ditolak. Hipotesis keenam menyatakan kinerja manajerial dimoderasi gaya kepemimpinan dipengaruhi informasi akuntansi. Untuk membuktikannya, nilai pvalues harus melebihi nilai koefisien yaitu, 0,05 . Dari hasil perhitungan smartPLS menjelaskan bahwa informasi akuntansi tidak memiliki pengaruh terhadap kinerja manajerial yang dimoderasi gaya kepemimpinan. Dalam penelitian ini nilai p-values informasi akuntansi terhadap kinerja manajerial dengan efek moderating sebesar 0,967 besar dari nilai koefisien. Sehingga hipotesis tidak berpengaruh, artinya hipotesis keenam ditolak. Hipotesis ketujuh menyatakan kinerja manajerial yang dimoderasi gaya kepemimpinan dipengaruhi komitmen organisasi. Dari hasil perhitungan smartPLS menjelaskan bahwa informasi akuntansi tidak memiliki pengaruh terhadap kinerja manajerial yang dimoderasi gaya kepemimpinan. Untuk membuktikannya, nilai pvalues harus melebihi nilai koefisien yaitu, 0,05. Dalam penelitian ini nilai p-values komitmen organisasi terhadap kinerja manajerial dengan efek moderating sebesar 0,758 , lebih besar dari nilai koefisien 0,05. Sehingga dapat disimpulkan, hipotesis tidak berpengaruh, artinya hipotesis ketujuh ditolak 


\section{Pembahasan}

Hasil perhitungan smartPLS menjelaskan bahwa partisipasi anggaran tidak memiliki pengaruh terhadap kinerja manajerial. Untuk membuktikan kinerja manajerial tidak dipengaruhi oleh partisipasi anggaran, nilai $\mathrm{p}$-values harus melebihi nilai koefisien yaitu, 0,05. Dalam penelitian ini nilai $\mathrm{p}$ values partisipasi anggaran sebesar 0,176 , lebih besar dari nilai koefisien 0,05. Sehingga dapat disimpulkan, hipotesis tidak berpengaruh, artinya hipotesis pertama ditolak. Hasil penelitian ini berbeda dengan penelitian [32] dimana partisipasi anggaran memiliki pengaruh positif terhadap kinerja manajerial. Hasil ini disimpulkan pada setiap terjadinya perubahan sekian kali satuan partisipasi anggaran secara relative akan meningkatkan kinerja manajerial. Dan [13] dalam penelitiannya juga memperlihatkan bahwa hubungan partisipasi anggaran dengan kinerja manajerial mempunyai hasil berpengaruh signifikan. Dan penelitian dari [14], menjelaskan bahwa kinerja manajerial dapat dipengaruhi secara signifikan oleh partisipasi anggaran. Hal ini dapat mendorong manajer untuk berperan lebih aktif pada pelaksanaan anggaran dalam menghadapi kesulitan yang muncul. Anggaran yang berhasil, harus melibatkan bawahan dalam tanggung jawab pengendalian biaya untuk membuat estimasi anggaran.

Hasil perhitungan smartPLS menjelaskan bahwa informasi akuntansi memiliki pengaruh pada kinerja manajerial. Untuk menentukan kinerja manajerial dapat dipengaruhi oleh informasi akuntansi, nilai pvalues harus kecil dari nilai koefisien yaitu, 0,05. Dalam penelitian ini nilai p-values informasi akuntansi sebesar 0,039 kecil dari nilai koefisien. Sehingga hipotesis berpengaruh, artinya hipotesis kedua diterima. Hasil penelitian ini sepaham dengan [33] yang menjelaskan dalam penelitiannya, jika informasi akuntansi memiliki pengaruh pada kinerja manajerial. Begitu juga dengan hasil peneltian [17] bahwa sistem informasi akuntansi memiliki pengaruh yang signifikan pada kinerja manajerial. Hasil ini dibuktikaan dengan adanya informasi kinerja yang komprehensif dan sistem pengukuran kinerja yang dapat menghasilkan infromasi lebih spesifik dan relevan dalam proses pengambilan keputusan yang dapat meningkatkan kinerja manajerial.

Dari hasil perhitungan smartPLS menjelaskan bahwa komitmen organisasi tidak memiliki pengaruh terhadap kinerja manajerial. Untuk membuktikannya nilai $p$-values harus lebih besar dari nilai koefisien yaitu, 0,05. Dalam penelitian ini nilai p-values komitmen organisasi adalah 0,515 , nilai tersebut besar dari nilai koefisien. Sehingga dapat disimpulkan, hipotesis tidak berpengaruh, artinya hipotesis ketiga ditolak. Hasil penelitian ini tidak sejalan dengan hasil penelitian [14] yang hasilnya yaitu, kinerja manajerial dipengaruhi secara signifikan oleh komitmen organisasi. Sehingga ini memperlihatkan karyawan yang komit terhadap organisasi akan memberikan sikap dan loyalitas yang tinggi dalam mewujudkan tujuan organisasi.

Hasil perhitungan smartPLS menjelaskan bahwa gaya kepemimpinan memiliki pengaruh terhadap kinerja manajerial. Untuk menentukan kinerja manajerial dipengaruhi oleh gaya kepemimpinan, nilai p-values harus lebih kecil nilai koefisien yaitu, 0,05 . Dalam penelitian ini nilai $p$-values informasi akuntansi sebesar 0,036 kecil dari nilai koefisien. Sehingga hipotesis berpengaruh, artinya hipotesis keempat diterima. Hasil penelitian ini sejalan dengan Penelitian [23] yang menyatakan bahwa gaya kepemimpinan berpengaruh positif terhadap kinerja manajerial. gaya kepemimpinan memiliki pengaruh penting dalam meningkatkan pencapaian tujuan organisasi. Manajer yang mampu menerapkan gaya kepemimpinan sesuai dengan keinginan karyawan dapat membuat karyawan mampu lebih berusaha untuk meningkatkan keoptimalan kinerja mereka. Sedangkan hasil penelitian ini tidak sepaham dengan hasil penelitian dari [22] yang memiliki hasil gaya kepemimpinan tidak memiliki pengaruh pada kinerja manajerial.

Dari hasil perhitungan smartPLS menjelaskan bahwa kinerja manajerial yang dimoderasi gaya kepemimpinan tidak dapat dipengaruhi oleh partisipasi anggaran. Untuk membuktikan hasil tersebut, nilai p-values harus melebihi nilai koefisien yaitu, 0,05. Dalam penelitian ini nilai p-values partisipasi anggaran terhadap kinerja manajerial dengan efek moderating sebesar 0,949 , lebih besar dari nilai koefisien 0,05 . Sehingga dapat disimpulkan, hipotesis tidak berpengaruh, artinya hipotesis kelima ditolak. Hasil ini tidak sesuai dengan penelitian [16] yang menyatakan partisiapasi anggaran mempunyai pengaruh pada kinerja manajerial menggunakan gaya kepemimpinan sebagai variabel moderasi. Hal ini menjelaskan sifat consideration dimiliki variabel gaya kepemimpinan, artinya terdapat hubungan terhadap pimpinan dan bawahan yang saling mempercayai dan saling memperhatikan. Sehingga, bawahan memiliki kesempatan lain yang diberikan manajer untuk dapat berperan aktif menyusun partisipasi anggaran yang dapat meningkatkan kinerja manajerial.

Dari hasil perhitungan smartPLS menjelaskan bahwa informasi akuntansi tidak memiliki pengaruh terhadap kinerja manajerial yang dimoderasi gaya kepemimpinan. Untuk membuktikannya, nilai pvalues harus melebihi nilai koefisien yaitu, 0,05. Dalam penelitian ini nilai $p$-values informasi akuntansi terhadap kinerja manajerial dengan efek moderating adalah 0,967 , yang nilainya besar dari nilai koefisien. Sehingga hipotesis tidak berpengaruh, artinya hipotesis keenam ditolak. Hasil penelitian ini bertolak belakang dengan penelitian yang dilakukan [16] yang menunjukkan infromasi akuntansi memiliki pengaruh terhadap kinerja manajerial 
dengan menggunakan gaya kepemimpinan sebagai variabel moderasi. Gaya kepemimpinan yang baik, yakni sebuah hubungan atasan dan bawahan harus mempunyai rasa kepercayaan dan saling memperhatikan. Hal ini dapat membuat bawahan mempunyai perasaan telah dihargai dan dapat melakukan pekerjaan lebih untuk perusahaan. Informasi yang cukup dan diperkuat dengan gaya kepemimpinan yang baik dapat memberikan peningkatan pada kinerja manajerial. Agar memanfaatkan informasi yang cukup dan diperkuat oleh gaya kepemimpinan yang baik dapat meningkatkan kinerja manajerial.

Dari hasil perhitungan smartPLS menjelaskan bahwa informasi akuntansi tidak memiliki pengaruh terhadap kinerja manajerial dimoderasi gaya kepemimpinan. Untuk membuktikannya, nilai pvalues harus melebihi nilai koefisien yaitu, 0,05. Dalam penelitian ini nilai p-values komitmen organisasi pada kinerja manajerial dengan efek moderating adalah 0,758 besar dari nilai koefisien. Sehingga hipotesis tidak berpengaruh, artinya hipotesis ketujuh ditolak. Hasil ini sejalan dengan penelitian dari [13] menjelaskan bahwa komitmen organisasi tidak memiliki pengaruh pada kinerja manajerial dimoderasi oleh gaya kepemimpinan. Sehingga bisa dikatakan gaya kepemimpinan tidak mempunyai pengaruh besar pada kinerja manajerial.

\section{Simpulan, Keterbatasan, Implikasi, Dan Saran}

Penelitian ini bertujuan menganalisis adanya faktor penentu kinerja manajerial. Faktorfaktor tersebut partisipasi anggaran, informasi akuntansi, dan komitmen organisasi. Lalu gaya kepemimpinan memoderasisetiap hubungan antara faktor-faktor tersebut terhadap kinerja manajerial. Untuk menganalisis hubungan tersebut, penelitian ini menggunakan Partial Least Square (PLS). Berdasarkan hasil penelitian dan pembahasannya pada bab sebelumnya, maka dapat disimpulkan, Hasil uji hipotesis pertama ditemukan partisipasi anggaran tidak memiliki pengaruh pada kinerja manajerial. Hasil uji hipotesis kedua ditemuka jika informasi akuntansi memiliki pengaruh pada kinerja manajerial. Hasil pengujian hipotesis ketiga ditemukan bahwa komitmen organisasi tidak memiliki pengaruh pada kinerja manajerial. Hasil uji hipotesis keempat ditemukan jika gaya kepemimpinan mempunyai pengaruh pada kinerja manajerial. Hasil uji hipotesis kelima ditemukan bahwa partisipasi anggaran tidak memiliki pengaruh pada kinerja manajerial menggunakan gaya kepemimpinan sebagai variabel moderasi. Hasil pengujian hipotesis keenam ditemukan jika informasi akuntansi tidak mempunyai pengaruh pada kinerja manajerial menggunakan gaya kepemimpinan sebagai variabel moderasi. Hasil uji hipotesis ketujuh ditemukan jika komitmen organisasi tidak mempunyai pengaruh pada kinerja manajerial dengan menggunakan gaya kepemimpinan sebagai variabel moderasi

Hasil penelitian ini mempertimbangkan adanya keterbatasan dalam melakukan penelitian. Beberapa dari keterbatasan penelitian ini di antaranya sebagai berikut: a) Objek penelitian ini terbatas pada kepala bidang keuangan pada rumah sakit dan klinik yang ada di Kota Padang, sehingga hasil penelitian tidak dapat digeneralisasi untuk kepala bidang keuangan di rumah sakit adan klinik secara keseluruhan. b) Penelitian ini hanya menggunakan media kuesioner, sehinggan masih dimungkinkan terdapat kelemahan-kelemahan, seperti jawaban dari responden yang kurang serius, asal-asalan, kurang cermat dan tidak jujur. Selain itu pertanyaan didalam kuesioner yang kurang lengkap dan pertanyaan yang tidak mudah dipahami responden. c) faktor-faktor yang digunakan dalam penentuan kinerja manajerial seperti partisipasi anggaran, informasi akuntansi, komitmen organisasi dan terhadap variabel moderasi yakni gaya kepemimpinan, masih memiliki kekurangan dalam pembahasannya.

Penelitian ini terdapat dua teori yaitu teori penetapan tujuan dan teori kontinjensi, dimana teori ini memaparkan secara jelas bagaimana variabel independen mampu mempengaruhi variabel dependen dengan dimoderasi oleh variabel moderasi. Sehingga penelitian ini dapat menjelaskan secara rinci maksud dan tujuan penelitian. Berdasarkan teori yang diangkat dalam penelitian ini, peneliti berharap penelitian ini dapat dipraktekkan dalam kegiatan kerja, sehingga apa yang menjadi tujuan peneliti dapat tersampaikan dengan baik. Adapun dari hasil penelitian yang telah dilakukan, ada beberapa saran yang dapat peneliti berikan antara lain: a) Agar hasil penelitian ini bisa digeneralisasi, penelitian berikutnya harus mampu memperbanyak objek penelitian yang tidak hanya satu saja, dalam hal ini kepala bidang keuangan rumah sakit dan klinik di Kota Padang tetapi misalkan pada semua kepala bidang yang terdapat pada rumah sakit atau klinik di kota Padang atau memperluasnya ke kepala bidang keuangan rumah sakit dan klinik di Sumatera Barat ataupun di Indonesia. b) Untuk menghindari rsponden yang kurang objektif dalam mengisi dan menjawab setiap pertanyaan yang terdapat dalam kuesioner, peneliti selanjutnya disarankan menggunakan metode yang mampu membuat responden nyaman dalam menjawab pertanyaan seperti menggunkan kertas warna-warni atau menyediakan hadiah bagi yang mengisi kuesioner atau juga bisa melakukan wawancara dan observasi secara langsung dan mengumpulkan data. Sehingga data lebih akurat dan efisien, dan juga sesuai dengan keadaan yang sebenarnya. c) Penelitian selanjutnya dapat memperbaiki kekuarangan yang ada pada

91 | Jurnal Akuntansi, Ekonomi dan Manajemen Bisnis | Vol. 8 No.1, July 2020, 82-93 | E-ISSN: 2548-9836 
penelitian ini atau dapat menambah faktor-faktor lain yang belum termasuk dalam model regresi penelitian ini, seperti locus of control, karakteristik informasi akuntansi, motivasi kerja, sehingga hasil penelitian lebih luas dibandingkan dengan peneliti sebelumnya.

\section{Daftar Pustaka}

A. J. Jermias and T. Setiawan, "The moderating effects of hierarchy and control systems on the relationship between budgetary participation and performance," Int. J. Account., vol. 43, pp. 268-292, 2008.

B. C. M. Lau and E. W. Lim, "The effects of procedural justice and evaluative styles on the relationship between budgatry participation and performance," Adv. Accounting, vol. 19, pp. 139-160, 2002.

C. A. Agbejule and L. Saarikoski, "The effect of cost management knowledge on the relationship between budgetary participation and managerial performance," Br. Account. Rev., vol. 38, pp. 427-440, 2006.

D. R. Rastogi and V. Dave, "Managerial Effectiveness: A Function of Personality Type and Organisational Components," Singapore Manag. Rev., vol. 26, no. 2, pp. 79-87, 2004.

E. R. Ghasemi, H. R. Habibi, M. Ghasemlo, and M. Karami, "The effectiveness of management accounting systems: evidence from financial organizations in Iran," J. Account. Emerg. Econ., vol. 9, no. 2, pp. 182-207, 2019.

F. E. A. Locke and G. P. Lathan, "New directions in Goal-setting theory," Curr. Dir. Psychol. Sci., vol. 15, no. 5, pp. 265-268, 2006.

G. D. T. Otley, "The contingency theory of management accounting: Achievement and prognosis," Accounting, Organ. Soc., 1980.

H. P. Brownell and M. McInnes, "Budgetary Participation, Motivation, and Managerial Performance," Account. Rev., vol. 61, no. 4, pp. 587-600, 1986.

I. V. Frucot and S. White, "Managerial levels and the effects of budgetary participation on managers," Manag. Audit. J., vol. 21, no. 2, pp. 191-206, 2006.

J. P. Brownell, "Participation in budgeting, locus of control and organizational performance," Account. Rev., vol. 56, no. 4, pp. 844-860, 1981.

K. J. Shields and M. D. Shields, "Antecedeants of Participative Budgeting," Accounting, Organ. Soc., vol. 23, no. 1, pp. 49-76, 1998.

L. G. N. Triseptya, G. Pagalung, and A.
Indrijawati, "The Effect Of Budget Participation, Organizational Commitment And Culture On Managerial Performance With Leadership Style As Moderating," SEIKO J. Manag. Bus., pp. 36-46.

M. D. R. Wuner and A. Subardjo, "Pengaruh Partisipatif Anggaran, Komitmen Organisasi Terhadap Kinerja Manajerial Pt Jasa Marga Tbk," J. Ilmu dan Ris. Akunt., vol. 5, no. 9, pp. 1-20, 2016.

N. D. Kocsis, "A conceptual foundation of design and implementation research in accounting information systems," Int. J. Account. Inf. Syst., no. xxxx, 2019.

O. A. L. Nuraini and Rosyati, "Pengaruh partisipasi anggaran dan informasi akuntansi terhadap kinerja manajerial: komitmen organisasi, gaya kepemimpinan, ketidakpastian tugas, ketidakpastian lingkungan Dan strategi bisnis sebagai variabel moderasi," in Proceedings of Conference in Business, Accounting and Management, 2012, vol. 1, no. 1, pp. 99-120.

P. M. I. Tyas and R. R. Sitorus, "Pengaruh Tekanan Anggaran Waktu Dan Tingkat Efektivitas Sistem Informasi Akuntansi Terhadap Kinerja Manajerial Dengan Keahlian pemakai komputer akuntansi sebagai pemoderasi," J. Akunt. Manajerial, vol. 1, no. 2, pp. 59-70, 2016.

Q. A. Eliyana, S. Ma'arif, and Muzakki, "Job satisfaction and organizational commitment effect in the transformational leadership towards employee performance," Eur. Res. Manag. Bus. Econ. https//doi.org/10.1016/j.iedeen.2019.05.001, 2019.

R. B. P. Mathews and J. L. Shepherd, "Dimensionality of Cook and Wall's (1980) British Organizational Commitment Scale revisited," J. Occup. Organ. Psychol., 2002.

S. M. A. Djalil, M. Indriani, and Muttaqin, "The Influence of Organizational Commitment and Motivation in the Relationship between Budget Participation and Managerial Performance (Empirical Study on Provincial Government Agencies ( SKPA) of Aceh Province, Indonesia)," Brand Res. Accounting, Negoc. Distrib., vol. 8, no. 1, pp. 12-24, 2017.

T. S. Oreg and Y. Berson, "Leadership and employees' reactions to change: The role of leaders' personal attributes and transformational leadership style," Pers. Psychol., vol. 64, no. 3, pp. 627-659, 2011.

U. H. Rudhianto, "Pengaruh Komitmen Organisasi dan Gaya Kepemimpinan Terhadap Hubungan Antara Partisipasi Anggaran dan Kinerja (Studi Empiris di Universitas Sebelas Maret)," pp. 162, 2010. 
V. L. Hakim, H. T. Asmony, and B. A. Inapty, "Pengaruh komitmen organisasional, sistem pengendalian intern pemerintah, dan gaya kepimpinan terhadap kinerja manajerial (survey pada SKPD Sumbawa dan Sumbawa Barat)," JAFFA, vol. 04, no. 2, pp. 67-82, 2016.

W. R. Ruvendi, "Kepemimpinan Kerja," J. Ilm. Binaniaga, vol. 01, no. 1, pp. 17-26, 2005.

X. M. F. Baihaqi, "Pengaruh gaya kepemimpinan terhadap kepuasan kerja dan kinerja dengan komitmen organisasi sebagai variabel intervening," Universitas Diponegoro, 2010.

Y. V. Govindarajan and A. K. Gupta, "Linking control systems to business unit strategy: impact on performance," Accounting, Organ. Soc., 1985.

Z. K. Milani, "The Relationship of Participation in Budget-Setting to Industrial Supervisor Performance and Attitudes: A Field Study," Account. Rev., 1975.

AA. R. T. Mowday, R. Steers, and L. W. Porter, "The measurement of organizational commitment ," J. Vocat. Behav., vol. 14, no. 2, pp. 224-247, 1979.
BB. S. Holmes and D. Nicholls, "an Analysis of the Use of Accounting Information By Australian Small Business.," Journal of Small Business Management. 1988.

CC. J. Hulland, "Use of partial least square (PLS) in strategic management research: a review of four recent studies," Strateg. Manag. J., vol. 20, pp. 195-204, 1999.

DD. R. R. Bagozzi and Y. Yi, "On the Evaluation of Structural Equation Models," J. Acad. Mark. Sci., vol. 16, no. 1, pp. 74-94, 1988.

EE. D. W. Sari, M. Arfan, and S. Abdullah, "Pengaruh Partisipasi Penyusunan Anggaran, Kepuasan Kerja, Job Relevant Information dan Motivasi Kerja Terhadap Kinerja Manajerial Kejaksaan Negeri Wilayah Aceh," J. Megister Akunt., vol. 6, no. 2, pp. 20-31, 2017.

FF. D. Efendi, "Pengaruh informasi akuntansi terhadap kinerja manajer dengan ketidakpastian tugas sebagai variabel moderasi (studi empiris terhadap koperasi di eks. karesidenan Madiun)," Universitas Diponegoro, 2001. 